\title{
KORKU MEKANLARI: TERÖR KORKUSUNUN MEKANSAL BOYUTU VE KAÇINMA DAVRANIŞI ${ }^{1,2,3}$
}

\section{Tuba GÜN ÇINĞI ${ }^{4}$}

\section{ÖZ}

Terör korkusu, son yıllarda dünya çapında gerçekleşen ve büyük oranda sivil halkı hedef alan terör saldırılarının ortaya çıkardığı önemli bir sorundur. Bu korku pek çok unsur tarafından tetiklenebilmektedir. Araştırmanın temel amacı, terör korkusu ile mekan ilişkisini ortaya koymak ve korkunun belirli mekanlarda yoğunlaşıp yoğunlaşmadığını saptamaktır. Araştırmanın teorik çerçevesini, suç korkusunu mekanın fiziksel ve sosyal özellikleri bağlamında ele alan kentsel organizasyonsuzluk teorilerden düzensizlik, sosyal kontrol ve altkültürel çeşitlilik teorileri oluşturmaktadır. Dünya risk toplumu teorisi, araştırma kapsamında faydalanılan bir diğer teorik bağlamdır. Araştırma verileri, 2018 yılında Ankara'da gerçekleştirilen 400 anket ve 20 görüşmenin sonuçlarına dayanmaktadır.

Araştırma sonuçları, terör korkusunun belirli mekanlarda diğerlerine göre daha çok hissedildiğini ortaya koymaktadır. Ayrıca düzensizlik ve sosyal kontrol teorileri gibi suç korkusu teorilerinin, terör korkusunu açıklayamadığı, altkültürel çeşitlilik teorisinin ise korkunun mekansal yoğunlaşması üzerinde nispeten açıklayıcı olduğu ortaya konulmuştur. Araştırma, Türkiye'de terör korkusunun mekansal yoğunluğunu ve bunu tetikleyen faktörleri ortaya koyması açısından literatür için önem arz etmektedir.

Anahtar Kelimeler: Terör Korkusu, Mekân, Kaçınma Davranışı, Ankara

\footnotetext{
${ }^{1}$ Çalışma, Anadolu Üniversitesi Sosyal Bilimler Enstitüsü'nde kabul edilen ve yayımlanmamış doktora tezinden türetilmiştir.

${ }^{2}$ Çalışma, Anadolu Üniversitesi BAP Komisyonunca kabul edilen 1601 E012 no.lu proje kapsamında desteklenmiştir.

${ }^{3} \mathrm{Bu}$ çalışmanın özet metni, 19- 21 Eylül 2019 tarihleri arasında Ankara'da gerçekleştirilen 9. Ulusal Sosyoloji Kongresi'nde sözlü olarak sunulmuştur.

${ }^{4}$ Arş. Gör. Dr., Adıyaman Üniversitesi Fen - Edebiyat Fakültesi, Sosyoloji Bölümü 


\section{SPACES OF FEAR: SPATIAL DIMENSION OF FEAR OF TERROR AND} AVOIDANCE BEHAVIOR

\section{ABSTRACT}

Fear of terrorism is an important problem caused by terrorist attacks that have been carried out across the world in recent years, targeting mostly civilian people. This fear can be triggered by many elements. The main purpose of this study is to reveal the relationship between the fear of terrorism and space and to determine whether fear is intensified in certain places. The theoretical framework of the research consists of theories of disorder, social concern/control and subcultural diversity which are the theories of social disorganization that address the fear of crime in the context of the physical and social characteristics of space. Theory of world risk society is another theoretical context within the scope of the research. The research data is based on the results of 400 surveys and 20 interviews conducted in Ankara in 2018.

The results of the research show that the fear of terror is felt more in certain places than the others. Also, theories of fear of crime such as disorder and social control theories cannot explain the fear of terrorism, but the theory of subcultural diversity is relatively explanatory on the spatial concentration of fear. Research is important for literature because it reveals the spatial intensity of the fear of terrorism in Turkey and the factors that trigger it.

Keywords: Fear of Terror, Space, Avoidance Behavior, Ankara 


\section{GíRiş}

Suç, toplumun yerleşik normlarından sapmış ve kanun koyucu tarafindan cezai yaptırım uygulanan davranışlardır. Bu nedenle de genel olarak, çözüme ulaştırılması gereken sosyal bir problemdir (Dönmezer, 1994: 23, 47). Suç, tarihteki ilk toplumlardan bu yana varlık göstermektedir. Ancak sanayileşme ve yoğun kentleşme suçun daha çok kentsel mekânla ilişkilendirilmesinin önünü açmıştır ve suç, önemli bir kent sorunu haline gelmiştir. Suçu kent bağlamında değerlendiren ilk çalışmalar Chicago Okulu'na dayanmaktadır. Okulun takipçilerinden Shaw ve McKay, suç olaylarının temelinde, kentsel mekanın fiziki ve sosyal çevresel düzensizlikleri olduğunu savunan sosyal düzensizlik teorisini ortaya koymuşlardır (Hunter, 1978: 1; Dolu, 2015: 224- 227). Okulun önemli bir diğer temsilcisi Wirth'ün tanımladığı; kentleşme ile ortaya çıkan ikincil ilişkilere dayalı, parçalı, sosyal dayanışma ve kontrolün çözüldüğü kentli yaşam biçimleri (2002: 85) de suçun genel olarak kentlerle özdeşleştirilmesine yol açmıştır. Dolayısıyla suçun mekanı olan kent, aynı zamanda güvensizliğin, kaygının ve korkunun da mekânı haline gelmiştir. Bu durum, suçun yanı sıra, suç korkusunu da bir ‘sosyal problem’ olarak büyük ölçüde bir kent sorunu olarak karşımıza çıkarmaktadır.

Terör mağduru olma korkusu, özellikle 11 Eylül 2001 saldırıları sonrası uluslararası boyutta çok büyük ölçüde artış gösteren bir problem olarak karşımıza çıkmaktadır. Terör korkusuna ve risk algısına ilişkin uluslararası boyutta azımsanmayacak bir literatürden bahsedilebilir (Beck, 2002a; 2002b; Sanadjian, 2006; Semmerling, 2008; Aly ve Green, 2010; Ahmed, 2015; Khruakham ve Lee, 2014; Nellis ve Savage, 2012; Durodie, 2007; Pain ve Smith, 2008; Pain, 2010). Türkiye'de ise, ilgili literatürde oldukça az sayıda çalışmaya rastlanmaktadır (Irmak ve Kâhya, 2014; Mühürcüoğlu, 2010, Demirçivi, 2015). Beck, 11 Eylül'den sonra terör kavramının anlamının değiştiğini ifade etmiş (2002a: 39) ve bu terör eylemlerinin değiştirdiği yeni dünya için de "terroristic world risk society" (terörize edilmiş dünya risk toplumu) (Beck, 2002b: 9) ifadesini kullanmıştır. Nitekim 11 Eylül'le başlayan bombalı intihar saldırıları ve çeşitli terör eylemleri, son yıllarda Avrupa ve Asya başta olmak üzere dünyanın diğer bölgelerinde de sıklıkla gerçekleşir durumdadır. Türkiye'de yalnızca son bir kaç yılda Suruç (2015), Ankara Garı (2015), Kızılay (2015), İstiklal Caddesi (2016), Sultan Ahmet (2016), Atatürk Havalimanı 
(2016) ve Reina (2017) başlıcaları olmak üzere geneli sivilleri hedef alan çok sayıda terör saldırısı düzenlenmiştir. Bu saldırıların, özellikle halkın yoğun olarak bulunduğu kalabalık kamusal alanlarda gerçekleştirilmesi, genel bir korku ve endişeye yol açmıştır. Bu durum, mümkün olduğunca kalabalık alanlara girilmemesini ve günlük aktivitelerin sınırlandırılmasını beraberinde getirmiştir. $\mathrm{Bu}$ anlamda, terör suçu mağduru olma korkusu büyük ölçüde, herhangi bir statü, konum veya fiziki ve sosyal düzensizlikle sınırlandırılamayacak bir olgu olarak karşımıza çıkmaktadır. Düzensizlik teorisinin temel tezlerinden farklı olarak, terör suçu ve dolayısıyla da terör korkusu fiziki ve sosyal açıdan oldukça düzenli mekânlarda ortaya çıkmaktadır. Bu amaçla, araştırmanın, Türkiye'deki terör korkusu ve mekan ilişkisini daha spesifik olan suç korkusu ve daha genel olan dünya risk toplumu teorileri temelinde ele alması ve terör korkusu bağlamında mekanların nasıl kodlandığının tespit edilmesi açısından belirli bir boşluğu dolduracağı düşünülmektedir.

\section{TEORİK ÇERÇEVE}

$\mathrm{Bu}$ çalışmanın teorik arkaplanında, suç korkusu teorilerinden ve dünya risk toplumu teorisinden faydalanılmıştır. Suç korkusu literatüründe korkuya neden olan faktörlerin açılanmasında birden fazla modele gönderme yapılmaktadır. Ancak bu çalışma kapsamında, suç korkusu teorilerinden yalnızca sosyal organizasyonsuzluk bağlamında değerlendirilen ve korkuyu mekanın fiziki ve toplumsal dokusu ile ilişkilendiren düzensizlik, sosyal kontrol/ kaygı ve altkültürel çeşitlilik teorilerine yer verilecektir.

\subsection{Suç Korkusunu Açıklayan Teorik Yaklaşımlar}

Düzensizlik teorisi, suç korkusunu, çevrenin fiziki ve sosyal dokusuyla ilişki içerisinde ele almaktadır. Bu teoriye göre, “[k]entsel ortamda korku, her şeyden önce bireyi tehdit eden bir toplumsal düzensizlik korkusudur” (Hale, 1996: 37). Hunter'in (1978) “düzensizlik (incivility)”, Wilson ve Kelling'in (1982) "kırık camlar teorisi” olarak adlandırdıkları bu teori, kentsel yapıda ve yakın çevrede suç korkusuna yol açacak birtakım fiziki ve sosyal tehlike işaretlerinin varlığından bahseder. Buna göre, boş ve köhne ev ve arsalar, kırık camlar, pansiyon daireler, terk edilmiş arabalar, yere saçılmış çöpler ve döküntüler ve grafiti gibi unsurlar fiziksel ipuçlarıdır. Buna karşın, sokak serserileri, sokak kavgaları, sokak köşelerinde biriken gençler, sarhoşlar, gürültülü komşular, dilenciler ve fahişeler ise sosyal 
düzensizliğin ipuçlarıdır (Hunter, 1978: 7; Wilson ve Kelling, 1982: 3; Skogan, 1986: 212; Box, Hale ve Andrews, 1988: 341; Covington ve Taylor, 1991: 232). Bunlara ek olarak karanlık, yaya trafiğinin olmaması ve bilindik çevrede bilinmeyen yüzlerin varlı̆̆ı (Warr, 1990: 893- 894) da kayg1 ve korku yaratıcı unsurlar olarak görülmüştür.

Sosyal kaygl/ kontrol teorisi, genellikle sosyal düzensizlik teorisinin içinde ve onun bir parçası olarak ele alınmaktadır (Hartnagel, 1979; Wilson ve Kelling, 1982; Hale, 1996; McGarrel, Giacomazzi ve Thurman, 1997). Bu model, düzensizlik teorisinin bütün hipotezlerini içermekle birlikte, ondan farklı olarak, korku üzerinde esas belirleyici faktörün yakın çevrenin toplumsal bağlamı olduğunu savunmaktadır (Taylor ve Hale, 1986: 156- 164; Covington ve Taylor, 1991: 232). Bu teoriye göre, suç korkusu algılanan toplumsal çözülmenin sonucudur ve kentsel topluluğun ve yerel toplumsal kurumların çözülmeyle mücadele edebilecek kapasitesinin varlığı korku seviyesini düşürecektir (Lewis, Salem ve Szoc, 1980: 2).

Altkültürel çeşitlilik yaklaşımı ise, etnik ve kültürel heterojenliğin suç korkusuna yol açtığı yaklaşımını benimsemektedir. Bu yaklaşıma göre, etnik ve kültürel olarak heterojen toplumlarda sosyal bütünleşme ve entegrasyonun görece zayıf olması güvensizlik ve korkuyu arttırmaktadır (Covington ve Taylor, 1991: 232; Liska, Lawrence ve Sanchirico, 1982: 762). Toplumsal değişimin ve farklı toplumsal grupların birlikteliğinin toplumsal bütünleşmeyi engellemesi, toplumsal kontrol mekanizmasını da işlevsiz kılmaktadır. Özellikle de fiziki ve toplumsal düzensizliklerin var olduğu durumlarda, farklı olan gruplar çoğunlukla tehlike ve tehdit olarak algılanmakta ve kaygı ve korkuyu tetiklemektedir.

\subsection{Dünya Risk Toplumu ve Yeni Terörizm}

Gerek Giddens (2000: 37; 2004: 16- 19) gerek Beck (2014: 25) günümüzdeki manasılyla riski, modernliğin ve küreselleşmenin bir sonucu olarak görmektedirler. Küreselleşme ile birlikte günümüz dünyasını “dünya risk toplumu” olarak tanımlayan Beck’e (2014: 357) göre, ekolojik krizler, küresel ekonomik krizler ve ulusötesi terörist ağlar bu dünya risk toplumunun temel öğeleridir (2002b: 4; 2002a: 39- 40). Dünya risk toplumu teorisine göre, yeni riskler; neden ve sonuçları bakımından belirli bir 
coğrafi alan veya mekânla sınırlandırılamaz, sonuçları tam olarak öngörülemez, dolayısıyla da telafi edilemez ve sigortalanamaz risklerdir (Beck, 2006: 333- 334; 2014: 357- 358; 2005: 42, 51). Bu radikal belirsizlik ortamı ise, güvensizlik ve bireyselleşmeyi artırmaktadır (Beck, 2006: 336). Dünya risk toplumu teorisine göre, riskler bazı insanları daha fazla etkilemekle birlikte risk konumları sınıfsal konumlar değildir ve bütün toplumsal konum ve sınıflar riskten payını almaktadır (2014: 28- 51).

Ulus ötesi terörist ağlar, dünya risk toplumunun göstergelerinden biridir (Beck, 2002b: 4; 2002a: 3940). Bilgi ve iletişim teknolojilerindeki gelişmeler ve küreselleşme ile terörün mevcut yapısı da değişmiş ve yeni bir terörizm anlayışı ortaya çıkmıştır. Özellikle son yıllarda IŞíD tarafından gerçekleştirilen intihar saldırıları gibi planlı, sistemli ve örgütlü terör eylemlerinin yanı sıra kendiliğinden, gelişigüzel ve çok daha küçük çaplı terör eylemlerine de rastlanmaktadır. Bu eylemler zorunlu olarak her zaman belli bir siyasal ideolojik arka planın tezahürleri de değildirler. Ekim 2017'de Las Vegas'taki müzik festivaline, Kasım 2017'de ise Texas'ta bir kiliseye yönelik gerçekleştirilen, çok sayıda kişinin ölmesine ve yaralanmasına yol açan silahlı saldırılar bunun örnekleri arasındadır. Son zamanlarda İngiltere'nin çeşitli bölgelerinde yayaların üzerine araç sürülmesi gibi toplumda korku yaratan tekil eylemlere de rastlanmaktadır. Bu da bizi “yeni terörizm” (Laqueur, 2000) kavramına götürmektedir. Mümkün olduğu kadar daha fazla ölü sayısının hedeflendiği (Garrison, 2004: 268; Mythen ve Walklate, 2006: 382) bu terörizm anlayışında artık "seçiciliğin sonu”na (Garrison, 2004: 268) gelinmiştir. Beck, özellikle 11 Eylül saldırılarından sonra, bu terör eylemlerinin değiştirdiği yeni dünya için "terroristic world risk society" (terörize edilmiş dünya risk toplumu) (Beck, 2002b: 9) ifadesini kullanmaktadır.

Risk toplumundaki terör eylemleriyle birlikte korku ve güvensizlik de küreselleşmiştir (Mythen ve Walklate, 2008: 223). Özellikle de 11 Eylül olaylarının farklı toplumlarda yarattığı etkiler, "korkunun küreselleşmesi”ni (Ahmed, 2015: 547) işaret etmektedir. "Terörizm olmaksızın terörizm tehdidi" (Howie, 2005: 4) altında hissetme, korkunun küreselleştiğinin en bariz göstergesidir.

Ancak, riskin ve korkunun da küreselleștiği yaklaşımından farklı olarak, korkunun her zaman belirli yerlerde diğerlerinden daha fazla açığa çıktığını ifade eden ve bu görüşünü "korkuyu mekânsallaştırma" 
(placing fear) (Pain ve Smith, 2008: 20) ve "mekânsallaştırılmış korku" (spatialising fear) (Pain, 2010: 238) gibi kavramlarla ortaya koyan bir yaklaşım da söz konusudur. Bu bakış açısına göre, "Korkunun jeopolitiği gündelik yaşamdır" (Pain ve Smith, 2008), yani korku, kendini daha ziyade sosyal ve mekânsal bir gündelik yaşamda ortaya koymaktadır.

\section{YÖNTEM}

Çalışma, Ankara' da yaşayan bireylerin terör suçuna maruz kalma korkusunun mekân ile ilişkisini ortaya koymayı amaçlamaktadır. Bu amaçla, terörün ve dolayısıyla da terör korkusunun hangi mekânlarda daha fazla görünür olduğu ve hangi mekânlarla doğrudan ilişkilendirildiği ortaya konulmaya çalışılmaktadır.

Araştırma, Ankara'nın en merkezi noktaları olan Kızılay ve Ulus gibi nüfus açısından yoğun ve heterojen alanlarda; yaşayan, çalışan, vakit geçiren veyahut bu alanları bir geçiş noktası olarak kullanan; Ankaralı olan veya olmayan, 18 yaş üstü vatandaşları kapsamaktadır. Kızılay ve Ulus'un örneklem olarak seçilmesinde esas belirleyici ise, bu alanların daha önce bir bombalı terör saldırısını deneyimlemiş olmalarıdır. 10 Ekim 2015'te Ankara Gar kavşağında meydana gelen terör saldırısı, Ankara Sıhhiye Meydanı'nda düzenlenen Emek, Barış ve Demokrasi Mitingi’ni hedef alan ve 109 kişinin ölümüne neden olan bir terör eylemidir. 13 Mart 2016'da Kızılay Meydanı'ndaki Güvenpark yanında meydana gelen terör saldırısı ise, otobüs duraklarının yanından geçen bomba yüklü bir aracın infilak ettirilmesiyle gerçekleştirilen ve 37 kişinin ölümüne neden olan saldırıdır. Karma araştırma metodunun benimsendiği araştırmanın nicel boyutu, Mart 2018'de 400 anket ile tamamlanmıştır.

Araştırmanın nitel boyutu ise, kartopu örnekleme tekniği kullanılarak gerçekleştirilen 20 görüşmeden oluşmaktadır. Görüşmeler, Nisan 2018'de gerçekleştirilmiştir. Görüşme yapılacak kişilerin ankete katılanlardan farklı olarak Ankara Gar ve Güvenpark'ta yaşanan patlamaları uzaktan veya yakından deneyimlemiş olmaları gerekmektedir. Patlamaları doğrudan deneyimlemiş olmaktan kasıt doğrudan patlamanın olmuş olduğu alanda bulunup patlamayı görmek iken, uzaktan deneyimlemiş olmakla patlamanın sesini duyarak alandan kaçanları görmek, çı̆̆lıklarını duymak, o gün yaşanan panik 
ortamının yol açtığı durumları deneyimlemek kastedilmektedir. Görüşmeler ortalama olarak 45- 50 dakika sürmüştür.

Anketlerden elde edilen veriler SPSS programı aracılığıyla çözümlenmiştir. Açık uçlu cevaplar ise, belirli kodlar çıkartılarak daha genel kavramlar ve temalar altında sınıflandırılmıştır. Görüşmeler sonucu elde edilen veriler ise, içerik analizine tabi tutulmuştur. Elde edilen veriler alt kodlara ayrılmış, kodlar arası ilişkiler aracılığıyla çeşitli kategori ve temalar oluşturularak veriler analiz edilmiştir.

\section{BULGULAR VE YORUM}

\section{1. Örneklemin Sosyodemografik Özellikleri}

Anket gerçekleştirilen örneklem grubu 400 kişiden oluşmaktadır. Bu grubun \% 37'sini kadınlar, \% 63’ünü ise erkekler oluşturmaktadır. Katılımcıların \% 36,3’ü 18-24, \% 36,3’ü 25- 35 yaş aralığındayken \% 12,4'ü 36-45, \% 9,5'i 46- 55, \% 5,4'ü ise 56 yaş ve üzerindedir. Öğrenim durumları bakımından örneklemin \% 2,2'si okuryazar, \% 6,5'i ilköğretim (ilk ve ortaokul), \% 28'2'si ortaöğretim, \% 12,2'si yüksekokul, \% 38,5'i lisans ve \% 12,2'si ise lisansüstü derecesine sahiptir. Gelir dağılımına bakıldığında, örneklemin \% 38'i 0- 1400 TL, \% 24,1'i 1401- 2500 TL, \% 20,5’i 2501- 4000TL ve \% 17,5 'i ise $4000 \mathrm{TL}$ ve üzeri gelir grubunda yer aldığını belirtmiştir. Örneklemin \% 65,8'i Ankara'da yaşarken \% 34,2'si ise Ankara dışında yaşamaktadır. Ankara'da ikamet edenlerin \% 92,1'i merkez ilçelerde \% 7,9’u ise kırsal ilçelerde yaşamaktadır.

Araştırma kapsamında ayrıca, 6'sı kadın 14'ü erkek olmak üzere 20 kişi ile görüşme gerçekleştirilmiştir. Görüşülenlerin 1'i 18-24, 10'u 25- 35, 6's1 36- 45 ve 3'ü ise 46- 55 yaş gruplarında yer almaktadır. Eğitim durumları açısından; 2 tanesi ortaöğretim mezunu, 12'si lisans ve 6'sı yüksek lisans derecelerine sahiptir. Gelir dağılımları göz önünde bulundurulduğunda, görüşme gerçekleştirilen katılımcıların 6'sının 0- 1400TL, 4'ünün 1401- 2500TL, 6'sının 2501- 4000TL gelir aralığında olduğu ve 4'ünün 4000TL'nin üzerinde gelir sahibi olduğu görülmektedir. 


\subsection{Korku Mekânları}

Genel bir çerçeve sunmak açısından, öncelikle anket gerçekleştirilen örneklemin büyük kentlere ilişkin risk algıları tespit edilmeye çalışılmıştır. Buna göre, katılımcıların \%74'ü büyük kentleri giderek daha riskli gördüklerini ifade etmişlerdir. Açık uçlu olarak yöneltilen soruda, bu riskin kaynağını açıklarken teröre doğrudan vurgu yapanların oranı yalnızca \% 28,2'dir. Ancak söz konusu terör olduğu zaman katılımcıların yüzde 87.2 'sinin kendisini risk altında hissettiği, yüzde 60.6'sının ise bir terör saldırısına kurban gitmekten korktuğu görülmektedir (Tablo 1).

$\mathrm{Bu}$ araştırmada terör korkusuna etki eden unsurlardan biri olarak mekâna odaklanılmaktadır. Araştırma bulguları, teröre ilişkin korkunun belirli mekânlarla daha çok ilişkilendirildiğini ve belirli mekânlarda daha çok açığa çıktığını ortaya koymaktadır. Bu anlamda elde edilen veriler çeşitli kategoriler altında sinıflandırılmıştır.

\section{Tablo 1. Terör Korkusu ve Mekân İlişkisi}

\begin{tabular}{|c|c|c|c|c|c|c|}
\hline & 恶 & 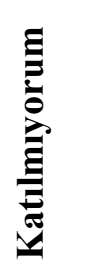 & 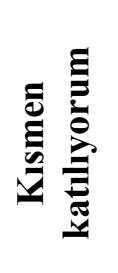 & 竭 & 泀 & $\begin{array}{c}\mathbf{f} \\
\%\end{array}$ \\
\hline Yakın gelecekte bir terör saldırısına kurban & 78 & 78 & 92 & 70 & 78 & 396 \\
\hline gitmekten korkuyorum & 19,7 & 19,7 & 23,2 & 17,7 & 19,7 & 100 \\
\hline Kalabalık yerlerde terör saldırılarına maruz & 58 & 50 & 105 & 81 & 104 & 398 \\
\hline kalmaktan korkuyorum & 14,6 & 12,6 & 26,4 & 20,4 & 26,1 & 100 \\
\hline AVM'lerde terör saldırılarına maruz & 68 & 64 & 104 & 74 & 87 & 397 \\
\hline kalmaktan korkuyorum & 17,1 & 16,1 & 26,2 & 18,6 & 21,9 & 100 \\
\hline Toplu taşıma araçlarında terör saldırılarına & 65 & 78 & 94 & 77 & 82 & 396 \\
\hline maruz kalmaktan korkuyorum & 16,4 & 19,7 & 23,7 & 19,4 & 20,7 & 100 \\
\hline
\end{tabular}




\subsubsection{Bir Mekân Olarak Kalabalık}

Terör eylemlerinin birincil amacı çok sayıda insan öldürmek değil, dehşet yaymak suretiyle bir korku toplumu oluşturmaktır. Bu durum, terör saldırılarının, gündelik yaşamın akışı içinde en yoğun kullanılan kamusal alanlara yönelmesini beraberinde getirmiştir. Türkiye ve dünyada yeni dönemde, şehir meydan1, tren garı, stadyum, konser, miting ve düğün gibi mekân ve etkinliklerin bombalanması, eğlence mekânlarının silahla taranması, kalabalık merkezi caddelerde halkın üzerine araç sürülmesi gibi terör eylemleri, hedefin fiziksel değil sosyal niteliğinin göz önünde bulundurulduğunu ortaya koymaktadır. Hedef, ister konser, düğün, spor müsabakası gibi eğlence temelli aktiviteler, ister miting, eylem gibi ideolojik toplantılar isterse toplu taşıma ve geçiş güzergâhları olsun esas amaç korkutmak, yıldırmak ve sindirmektir ve bu noktaları hedef kılan şey çoğunlukla, bu alanların işlevi değil sayısal yoğunluğu, yani kalabalık olmasıdır. Nitekim Pain ve Smith (2008)'in de ifade etmiş olduğu gibi, korku, kendini sosyal ve mekânsal bir gündelik yaşamda ortaya koymaktadır, dolayısıyla da "korkunun jeopolitiğinin gündelik yaşam"dır. Araştırmanın nicel sonuçları, örneklemin \% 46,5'inin kalabalık yerlerde terör mağduru olmaktan korktuğunu, \% 26,4'ünün bu korkuya kısmen sahip olduğunu ve \% 27,2'sinin ise böyle bir korku taşımadığını ortaya koymaktadır. Kalabalık olma halinin korkuya etkisi kendisini aynı zamanda alışveriş merkezlerinin ve toplu taşıma araçlarının kullanımında da göstermektedir. Nicel araştırma verileri, örneklemin \% 40’tan fazlasının alışveriş merkezlerinde ve toplu taşıma araçlarında teröre maruz kalma korkusu yaşadığını ortaya koymaktadır. AVM ve toplu taşıma gibi kalabalık alanlarda terör mağduru olmaya ilişkin herhangi bir korku yaşamayanların oranı ise sırasıyla \% 33,2 ve \% 36,1'dir. Örneklemin geri kalanı ise bu alanlarda terör korkusu yaşadıklarına ilişkin net bir tavır ortaya koymamış ve "kısmen" korktuklarını ifade etmişlerdir.

"Kalabalık", terör saldırılarının yarattığı korkunun mekânla ilişkisi bağlamında görüşmelerde de karşılaşılan önemli bir unsurdur:

Spesifik mekândan ziyade, kalabalık yani insan kalabalı̆̆ının oranıyla ilgili kaygılarım oluyor genelde. Bunlara örnek verecek olursak yine alışveriş güzergâhı olan Kızılay gibi Taksim gibi yerler, alışveriş merkezleri beni tedirgin ediyor. Çünkü çok fazla söylenti dolaşmıştı. Bundan 
sonraki patlama Ankara'da bir AVM'de olacakmış, istihbarat geldi gibi. (...) Konserler beni tedirgin ediyor. Evet, konser gibi insanların yoğun bir şekilde toplandığg mekânlar, evet diyorum burda patlayabilir. (Kadın, 33, Güvenpark)

Daha çok kalabalığın olduğu yerlerde bu tarz eylemlerin olma olasılığı daha yüksek. Çünkü amaç daha fazla insanın ölmesi, amaç kaosun, terörün daha fazla topluma bi şekilde korkuyla şey yapılması. (Erkek, 29, Gar)

\subsubsection{Etiketlenmiş / Mimlenmiş Mekânlar}

Bellek, bireyin kendisinin, ait olduğu toplumun veya şahit olduğu diğer toplumların deneyimlerinden hareketle olaylar arasında ilişkiler geliştirebilme ve eşleştirebilme potansiyeline sahiptir. Dünyada ve Türkiye'de daha önce yaşanmış olan terör olayları, yaşanma biçimi, yaşandığı coğrafya ve mekânla ilişkili olarak hafızada yer etmekte ve sonraki muhtemel benzer olaylar aynı çağrışımı yeniden devreye sokmaktadır. Nitekim Connerton'ın (2009) da ifadesiyle aşina olunan bazı mekânlar diğerlerinden daha güçlü bir şekilde belli duygu ve deneyimleri çağrıştırmakta, daha önce mekânın deneyimlediği olaylar bir kod olarak o mekâna kazınabilmektedir. Bu anlamda katılımcılara terörle ilişkilendirdikleri belirli alanlar olup olmadığı sorulduğunda bu soruya, sahip oldukları bireysel ve toplumsal hafizalarından veya belleklerinde olay ve durumlar arası kurdukları ilişki biçimlerinden hareketle çok çeşitli cevaplar vermişlerdir.

Katılımcılar arasında terör denildiği zaman dünya genelinde bir mekan algısıyla mekân olarak Ortadoğu'yu, Türkiye'nin yaklaşık 50 yıllık terör deneyiminden hareketle ülkenin doğusunu zikredenler bulunmaktadır. Bunların yanı sıra, yakın zamanda deneyimledikleri terör saldırılarından hareketle bu saldırıların gerçekleştiği mekânları veya bunlarla benzerlik içeren başka mekânları ve daha önce gerçekleştirilen ve gerçekleşebilecek muhtemel bir saldırıyla özdeşleştirilen radikal grupların yoğun olarak yaşandığı mekânları terörle özdeşleştirme söz konusudur.

Dünya geneli için düşünecek olursam Ortadoğu, ... devlet terörü falan da tarih boyunca Ortadoğu için söylenebilir, yani Saddam Hüseyin falan. Afganistan'da parti olan Taliban. (...) 
Türkiye için söyleyecek olursam da, daha böyle Doğu, orda nedeni de orda terör dolayısıyla bi çok operasyonların yapılması. (...) Ankara'da Ulus diyebilirim. Hacı Bayram Veli Camisi etrafında. (...) Ankara'da Ulus diyeyim, İstanbul'da Fatih diyeyim. (Erkek, 24, Güvenpark) Şöyle bir algımız var maalesef; katliamın sanki coğrafyası bizim doğumuz gibi. (Kadın, 33, Gar ve Güvenpark)

Türkiye'deki en büyük terör şu anda dini terör örgütler, dinin kullandığı yerler. (...) Bu yüzden Hacı Bayram ve çevresi beni rahatsız ediyo. (Erkek, 43, Gar)

Ankara genelinde terörle özdeşleştirilen mekânların başında hem daha önce Ankara Gar'ında yaşanan terör saldırısı hem de "karışık" olarak ifade edilen toplumsal yapısı dolayısıyla Ulus ve Gar sıkça tekrarlanan cevaplardandır. Ayrıca yine Ulus'ta yer alan Hacı Bayram Veli Camisi ve çevresi son dönemde etkin terör eylemleri gerçekleştiren IŞi̇D ile ilişkilendirilen ve katılımcılar tarafından cübbeli, sarıklı ve şalvarlı olarak tanımlanan İslamcı grupların etkin olarak kullandığı bir mekân olarak görüldüğü için Ankara çapında terörle özdeşleştirilen başlıca mekânlardan biri olarak karşımıza çıkmaktadır. Ankara'da Ulus'un, Hacı Bayram Veli Camiinin, yine yukarıda örneklendiği üzere İstanbul'da Fatih'in terör mekânları olarak görülmesinde benzemezlikten kaynaklanan bir korkunun da etkili olduğu ifade edilebilir. Bireyler yapısı ve niteliği bakımından kendilerini ait hissetmedikleri ortamlara ve mekânlara ilişkin bir tedirginlik ve korku taşıyabilmektedirler:

..., radikal İslamcı görüntüsü diyeceğim tırnak içinde, bu tür bir insan gördügümde tedirgin oluyorum. İnançlı bir insan olduğum halde. Şalvar, sarık, cübbe tarzı kıyafetler giymiş insanların bana zarar verebileceğinden korkuyorum, yani tesettürlü olmadığım için. Belki beni kendince kâfir ilan edip bana zarar verebileceğini düşünüyorum. (Kadın, 33, Güvenpark)

Katılımcılardan bazıları, daha önce terör saldırılarının gerçekleşmiş olduğu alanların yanı sıra sosyal ve fiziksel olarak bu alanlarla benzerlik gösteren yerleri de terörle özdeşleştirdiklerini ve bu alanlardan korktuklarını belirtmişlerdir: 
İstanbul için havaalanı. (...) Ankara hakeza, havalalanı olabilir, Güvenpark kesinlikle, Kızılay meydanı kesinlike. Yani özellikle bu Kızllay binası, Güvenpark o üçgen diyeyim, Sakarya da buna dâhil hatta, sevmiyorum yani oraları, tehlike altında görüyorum. (Kadın, 31, Güvenpark)

\subsubsection{Beklenmeyen Mekân - Ankara}

Belirli mekânlara ilişkin geçmiş yaşam deneyimleri, bu mekanların bulunduğu coğrafya ve toplumsal hafızada karşılık geldiği konum, bu mekânların risk ve mağduriyetler açısından olumlu veya olumsuz olarak kodlanmasına ve etiketlenmesine yol açar. Bu durum, belirli mekânların terör ve korku ile özdeşleştirilmesine yol açarken başka bazı mekânları da bu eşleşmenin dışında tutmakta ve bu yöndeki beklentiyi en aza indirmektedir.

Katılımcılardan bazılarının bölgede gerçekleşen çatışmalar dolayısıyla terörü zihinlerinde "Doğu" ile eşleştirdiği ifade edilmişti. Bu durum, terörün zihinde belirli ve sınırlı bir coğrafya ile eşleştirilmesini ve bu sınırların ötesinde bir terör beklentisinin olmamasını beraberinde getirmiştir. $\mathrm{Bu}$ anlamda görüşülenlerden bazıları, terörü, mekânsal olarak Ankara' dan bağımsız değerlendirdiklerini ve ülkenin batısında, özellikle de başkentte terör riski algılamadıklarını ve bir korku yaşamadıklarını belirtmişlerdir:

Ankara'da kimsenin aklına gelmezdi sonuçta, genelkurmay Türkiye'nin hani beyni dedikleri, en önemli yer dedikleri yerdi yani sonuçta, orda oldu. Güvenpark dediğin hani sivil insanların kalabalık olduğu yerde oldu, Garda hani toplanmış sadece sivillerin olduğu, hiçbir şeyin olmadığı, öyle barış istemeye gelen insanların içinde oldu. (Erkek, 47, Gar ve Güvenpark)

Ya biz önceden mesela Ankara'nın çok, 10 Ekim'e gelmeden önce Ankara'nın güvenli olduğunu sanıyoduk, başta en güvensiz yerlerden bir Ankara, İstanbul yani. (Erkek, 29, Gar)

\subsubsection{Mekân Olarak İdeoloji}

Terör korkusu ve mekan ilişkisinde ortaya çıkan bir diğer unsur ideolojidir. Görüşülenlerden bir kısmı, terör eylemlerinin bilinçli olarak belirli düşünce ve talepleri olan bazı muhalif grupları hedef aldığını düşünmektedirler. Dolayısıyla da bu grupların bir araya geldikleri, toplandıkları mekanları terör ve terör 
korkusu ile özdeşleştirmektedirler. İdeolojik faaliyetlerin gerçekleştirildiği mekânlar ile korkunun eşleştirilmesi, mağduriyeti açıklayan teoriler arasında yer alan yaşam tarzı ve rutin aktiviteler teorileri ile açıklanabilir. Bu teorilere göre, bireylerin yaşam tarzlarıyla mağduriyetleri arasında bir ilişki söz konusudur (Bunch, Clay- Warner ve Lei, 2015: 1183). Yaşam biçimi, boş zaman etkinlikleri ve mesleki faaliyetler gibi günlük rutin aktiviteler sebebiyle farklı demografik gruplar arasında farklı mağduriyet biçimleri yaşanabilmektedir (McNeeley, 2015: 33; Policastro, 2013: 47- 48). Hindelang ve arkadaşları (1978), yaşam tarzının mağduriyetle ilişkisinde, birincisi dışarıda harcanan zamandan kaynaklanan mağduriyet riski, ikincisi ise, sosyal ilişki ve etkileşimler sonucu ortaya çıkan dolaylı mağduriyet olmak üzere iki temel unsurun varlığına işaret ederler. Bu ikinci unsur, özellikle azınlık üyesi olan gruplarda bulunma veya bunlarla ilişki içinde olmanın mağduriyet riskini arttırmasına vurgu yapmaktadır (Corkin vd., 2015: 407- 424). Dolayısıyla özellikle Ankara Gar önünde, bulunduğu siyasi ve toplumsal koşullar göz önünde bulundurulduğu zaman, belirli politik ve ideolojik angajmanları olan kuruluşlar tarafindan gerçekleştirilen bir eylemde terör mağduriyeti yaşanması ve mağdurların korkuyu bu ideolojik yakınlaşmaların olduğu mekanlarla ilişkilendirmesi yaşam tarzı teorisi ile açıklanmaya oldukça elverişlidir:

Yani kitlesel eylemlerin olduğu her yerde bu tür saldırılar yaşanılabilir. Önümüzde 1 Mayıs var. (...) Geçmişte Nevroz vardı, çok şükür bişey olmadı gibi. Yani bu tür şeylerde önlem almak lazım. (Erkek, 38, Gar)

Kalabalıklarda, özellikle miting alanlarında falan ya da bi basın açıklaması gibi durumlarda bulunurken bi tedirginlik hissettim her zaman. (Erkek, 30, Gar, Güvenpark ve İstiklal)

\subsubsection{Terörü İmleyen Mekânlar Olarak Güvenlik Bölgeleri}

Daha önce belirtildiği üzere, korkuya ilişkin imgelemler belirli mekânlarla ile eşleştirilir ve bu süreçte, korku maddesel hale büründükçe mekânsallaştırılmış korku (spatialized fear) ortaya çıkar (Pain ve Smith, 2008: 12). Görüşülen örneklem tarafından korkunun mekânsallaştırıldığı diğer yerler; polis karakollarının bulunduğu kamusal alanlar, terörle mücadele şubesi ve özel güvenlik bölgeleri gibi riskin algılandığı ve korku yaratacak imgelerin atfedildiği mekânlardır. Polis karakolları ve polisin yoğun 
olarak bulunduğu alanlar, emniyet güçlerine yönelebilecek olası bir terör eylemi ile ilişkilendirilerek güvensiz addedilmektedir. Özellikle, Ankara Yüksel Caddesi gibi oldukça kalabalık bir kentsel mekâna polis karakolunun kurulmuş olması, polise yönelik bir saldırıda geniş bir kitleyi etkileyebileceği düşüncesiyle korkutucu bulunmakta ve terörü imleyen bu mekândan uzak durulmaya çalışılmaktadır:

Şu an mesela Yüksel'de bir karakol var, yani ben geçmekten tedirgin oluyorum. Üst taraflardan dolanıyorum, o da korkutan bişey. Sonuçta korku dediğiniz şey korktuğunuz şey için bi önlem almanızı gerektirir, bizim önlemimiz de sadece yolu değiştirmek. (...) Yani sonuçta o sokağa her gün gitmek zorunda, her gün alışveriş yapmak zorunda, benim müşterilerim de hergün oralardan geçiyo geliyor. (Erkek, 47, Gar ve Güvenpark)

O yüzden biz mesela polisin yoğun olduğu yerden de geçmiyoduk. Mesela İstanbul'da Beşiktaş maçı sonrası patlayan, saldırı mesela direkt polisin olduğu yerde patlatıyolar. Çünkü maç çıkışı, polis arabalarla bekliyo. Sonra yine Beşiktaş’ın yukarısında bi park var, Maçka parkı, Maçka parkındaki patlamada da mesela saldırgan kendini infilak ederken 4 tane polis etrafinda, yine polisi hedef alan bi saldırıydı. O yüzden polislerin yanında daha az güvende hissettiğimiz oluyodu. (Erkek, 24, Güvenpark)

\subsubsection{Her An Her Yerde Olabilirlik}

Korku her ne kadar küresel ve yerel düzlemde belirli mekânlarla ilişkilendirilse de, riskin küreselleşmesi ve yeni terörizmin her yerde ortaya çıkabilme kapasitesi, coğrafi sınırları aşan yapısı güvensizlik ve korkuyu da küreselleştirmiş (Mythen ve Walklate, 2008: 223; Ahmed, 2015: 547) ve Beck'in (2014) ifadesiyle dünya, bir "dünya risk toplumu” halini almıştır. Beck, özellikle 9/11 sonrası ortaya çıkan süreci terörize edilmiş dünya risk toplumu (terroristic world risk society) (Beck, 2002b: 9) olarak kavramsallaştırmış ve riskin öngörülemez ve hesaplanamaz olmasına (Beck, 2014) vurgu yapmıştır. Bu durum, bazı katılımcılar tarafından terörün ve dolayısıyla teröre ilişkin korkunun herhangi belirli bir mekânla özdeşleştirmenin zor olduğu, terörün her an her yerde ortaya çıkabileceğini ve hiçbir yerin terör açısından güvenli olmadığı şeklindeki ifadelerde yer bulmuştur: 
Aslında her yer. Çünkü barda bile katliam oldu. Reina'da. O yüzden şey, her yer artık sanki. Önceden şey, çok spesifik bişeyler söyleyebiliyoduk, işte polis karakollarının olduğu bölgeler, işte bakanlıkların olduğu bölgeler, eylem alanları, miting alanları bilmem ne bilmem ne diyoduk, ama şimdi metroda da tehdit var, ora da bir terör alanına dönüşebilir veya işte başka bi yer de. (Kadın, 33, Gar ve Güvenpark)

Her an her yerde ölüme tesadüf etme potansiyeli, korkunun belirli mekân veya durumlardan bağımsız olarak hissedilmesi, Güvenpark ve Ankara Gar terörünü deneyimleyenlerde "sınırda bulunma" durumuyla pekişmiştir denilebilir. Görüşme gerçekleştirilen bireylerden bir kısmı, o gün hayatta kalmasına sebep olan tesadüflerden bahsederek her an başlarına bir şey gelebilme potansiyelini zihinlerinde gerçeklemişlerdir. Bu durum onların gündelik yaşantılarında tesadüfen gelişen olayları bir "kurtulma" veya "yakalanma" paradoksu içerisinde algılamalarına yol açmıştır. Tesadüfen gelişen bir olayın kendilerini olası bir terör eyleminden koruduğu mu yoksa mağduriyetlerine mi sebep olacağı düşüncesi önemli bir ikilem olarak karşımıza çıkmaktadır:

Güvenpark katliamından da böyle bir kenarından geçince, 2 dakikayla falan ordan da hayatta kalınca şöyle bir his doğdu. Yani özellikle ordan, binmiş olduğum bi otobüsle ölmüş olma ihtimalimi düşünüyorum artık, kaçırmış olduğum bir otobüsle hayatta kalmış olma ihtimalimi düşünüyorum. .... otobüs kaçırdığımda istemsiz bi şekilde şurdan bişey bana diyo ki kaçırdığın otobüsle hayatta kalmış olabilirsin. Bindiğimde de bu otobüse böyle salakça yetiştin yani, binmiş olduğun otobüsle ölmüş olabilirsin. Ya böyle bir şey böyle yapıştı kaldı. (Kadın, 33, Gar ve Güvenpark)

Ya hani o gün ölmemem için hiç bi sebep yoktu, Kızılaydaydım, bombanın patladığı saatte ordaydım, bombanın patladığı tam mevkiiden belki 2- 3 defa geçtim, yani bombanın ölüm çemberinde bulundum. (...) Sonra da o ölüm çemberinden bi sebep oldu işte çıktık. (Erkek, 24, Güvenpark) 


\subsubsection{Terör Korkusunun Başka Mekânlara Aktarılması}

Korku ve mekan ilişkisine odaklanan Pain'e (2010: 231) göre, korku, genellikle terör eylemlerinin gerçekleştiği yerlere yakın bölgelerde daha fazla görülmektedir. Korkunun her zaman ve herkesi kapsıyormuş gibi merkeze alındığı "korkunun küreselleşmesi” söylemini bir metaanlatı olarak görmektedir (2009: 468). Ancak, Avustralya gibi yakın geçmişte bir terör saldırısına maruz kalmayan bölgelerdeki korku ve risk algısı (Aly ve Green, 2010), “terörizm olmaksızın terörizm tehdidi” altında hissetme (Howie, 2005: 4) durumu korkunun sadece onun şartlarını ortaya çıkaran coğrafyalarda görülmediğini ortaya koymaktadır. Yeni terörizmin, özellikle iletişim teknolojileri aracılığıyla her an her yerde eylem gerçekleştirebilme, eylemleri destekleme veyahut teşvik edebilme kapasitesi, terör korkusunun, terörü deneyimlememiş, mekân, kent, ülke veya kıtalarda da ortaya çıkmasına yol açmaktadır. Korkunun başka mekanlarda ortaya çıkmasında yeni dönemdeki terörist eylemlerin erişim kapasitesinin dışında etkili olan başka faktörler de söz konusudur. Terör ve terör korkusu sadece bir deneyime, hafizayı oluşturacak olaylar bütününe bağlı olarak belirli mekânlarla özdeşleştirilmemiştir. Daha önceden herhangi bir terör saldırısı deneyimlememiş olan, toplumsal hafızada terörle birlikte yer almamış olan bazı mekânlar da daha önce terörü deneyimleyen mekânlara gösterdiği benzerlikler bakımından terör mekânları olarak kodlanabilmekte ve terör eylemleri ve korkusu benzer fiziki ve sosyolojik özellikleri olan daha geniş coğrafyalara, kentlere ve mekânlara aktarılmaktadır. Bu durum bizim örneklemimiz bağlamında Ankara'da terör eylemlerinin gerçekleştirildiği Kızılay ve Gar gibi mekânlarla ve yine Türkiye'deki diğer saldırıların gerçekleştirildiği havaalanı ve turistik mekânlarla insan yoğunluğu açısından benzerlik gösteren diğer mekânlar ve başka şehirlerde bu mekânlarla benzerlik gösteren mekânlar olarak karşımıza çıkmaktadır:

$\mathrm{Bu}$ olayların yaşandığı dönemlerde Espark'a (Eskişehir merkezinde bir AVM) gitmek istemiyordum. (...) Çünkü Eskişehir denilince akla en kalabalık, en işlek Espark, direkt akla gelir yani. Dolayısıyla nişanlıma trenden indiği zaman, mesela geleceği zaman, evim Espark’’n çok yakınındaydı, Espark'ın yanından geçme, içinden geçme, taksiye bin dolaşsın vesaire. (...) Mesela, yılbaşında mekâna gittik, Hilton oteline, normalde şey güvenlikli otel, üst kattayız falan 
ama mesela özel günlerde, bu Reina olayından sonra ben yılbaşında tedirgin oldum açıcçası.

Eskişehir bile olsa böyle mekânlarda potansiyel bir saldırı şeyi olabileceğini düşünüyorum. (Kadın, 31, Güvenpark)

\subsection{Terör Korkusu ve Mekanların Kullanımına İlişkin Tutumlar}

Terörün ve dolayısıyla da terör korkusunun belirli mekanlarla ilişkilendirilmesi, hatta bazen özdeşleştirilmesi bu mekanların kullanımına ilişkin belirli tutumların da ortaya çıkmasını beraberinde getirmektedir. Bu tutum, genellikle terörü çağrıştıran, terör korkusunu imleyen mekanlardan uzak durma, kaçınma davranışı şeklinde ortaya çıkmaktadır. Ancak az sayıda da olsa, bu kaçınma tutumunun benimsenmediği durumların varlığı da ortaya konulmuştur.

Tablo 2. Terör Korkusu ve Mekanların Kullanımına İlişkin Tutumlar

\begin{tabular}{|c|c|c|c|c|c|c|}
\hline & 导导 & 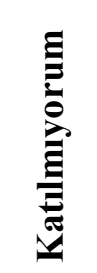 & 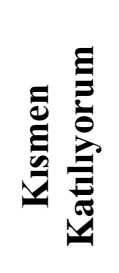 & 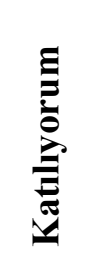 & 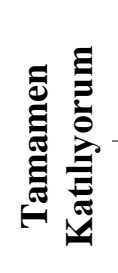 & $\%$ \\
\hline \multirow{2}{*}{$\begin{array}{l}\text { Terör korkusu nedeniyle kalabalık yerlerden } \\
\text { uzak durmaya çalışıyorum }\end{array}$} & 74 & 73 & 81 & 79 & 78 & 385 \\
\hline & 19,2 & 19,0 & 21,0 & 20,5 & 20,3 & 100 \\
\hline \multirow{2}{*}{$\begin{array}{l}\text { Terör korkusu nedeniyle alışveriş } \\
\text { merkezlerinden uzak durmaya çalışıyorum }\end{array}$} & 89 & 100 & 84 & 64 & 48 & 385 \\
\hline & 23,1 & 26,0 & 21,8 & 16,6 & 12,5 & 100 \\
\hline \multirow{2}{*}{$\begin{array}{l}\text { Terör korkusu nedeniyle toplu taşıma araçlarını } \\
\text { kullanmaktan kaçınıyorum }\end{array}$} & 103 & 111 & 92 & 36 & 42 & 384 \\
\hline & 26,8 & 28,9 & 24,0 & 9,4 & 10,9 & 100 \\
\hline \multirow{2}{*}{$\begin{array}{l}\text { Daha önce terör eylemlerinin gerçekleştiği } \\
\text { alanlardan uzak durmaya çalışıyorum }\end{array}$} & 77 & 81 & 92 & 65 & 66 & 381 \\
\hline & 20,2 & 21,3 & 24,1 & 17,1 & 17,3 & 100 \\
\hline
\end{tabular}

\subsubsection{Kalabalık Mekânlardan Kaçınma}

Kalabalık mekânlar, terör korkusunun en çok gözlemlendiği alanlardandır, dolayısıyla bu durum kaçınma davranışına da yansımaktadır. Buna göre terör korkusu nedeniyle kalabalık yerlerden uzak durmaya çalışanların oranı toplamda \% 61,8'dir (Tablo 2). Kalabalık mekanlardan kaçınma davranışının bir diğer yansıması alışveriş merkezlerinden ve toplu taşıma ağlarından kaçınma şeklinde ortaya çıkmaktadır. Buna göre, örneklemin \% 50,9’u terör korkusu nedeniyle alışveriş merkezlerinden uzak 
durmaya çalıştığını ifade etmiştir. Benzer sonuçları bulgulayan başka çalışmalar da söz konusudur. Örneğin, 2005 Londra terör eylemleri sonrasında gerçekleştirilen bir araştırma, örnekleminin \% 17'sinin Londra merkezinde daha az alışveriş yapmaya çalıştığını, \% 31'inin boş zaman aktivitelerinde, \% 3’ünün özel eğlence faaliyetlerinde azalma meydana geldiğini, \% 4'ünde ise diğer davranışsal değişiklikler gözlemlendiğini bulgulamıştır (Rubin vd., 2007). Toplu taşıma kullanımından kaçınma da terör korkusu nedeniyle rastlanılan bir davranış biçimidir. Terör korkusu ile toplu taşıma araçlarını kullanmaktan kaçınanların oranı yaklaşı \% $45^{\prime}$ tir.

Görüşmelerden elde edilen sonuçlar; kalabalık alanlardan, alışveriş merkezlerinden ve toplu taşıma araçlarından kaçınma davranışı aynı saiklerle tetiklendiği için birlikte ele alınmıştır. Ancak yüzdelik değerleri göz önünde bulundurulduğunda kalabalık alanlardan kaçınma davranışının en yüksek toplu taşımadan kaçınma davranışının ise en düşük yüzdelik değerlere sahip olduğu görülmektedir. Toplu taşımadan kaçınma davranışının diğer iki mekândan farklı olarak daha az gözlemlenmesinde özel araca sahip olmama ve toplu taşımanın daha ucuz olması gibi ekonomik sebepler etkilidir. Ayrıca, bu alanlardan kaçınma davranışının, terör eylemlerinin yoğun olarak gerçekleştiği dönemin üzerinden geçen zamanla paralel bir şekilde azalma göstermekle beraber, hala tam olarak ortadan kalkmış olduğu söylenemez:

Uzun bir süre bi çoğumuz koşarak yürüdük bütün caddeleri. Yani o kadar hızlı yürüdük ki sanki arkamızda böyle şey gibi, yeraltı canavarı gibi yani, uzun bi süre koşarak yürüdük. Ya diyoruz ki koşuyoruz sürekli sanki böyle şurda patlayacaktı da atlattım, hep atlattım hissiyle. Uzun bi süre böyle geçti gerçekten. (Kadın, 33, Gar ve Güvenpark)

Daha çok Kızılay'da dolaşmamaya başladım. Tedirginlikle dolaşmak beni psikolojik olarak rahatsız etti. O dönemlerde AVM'lere de çok gitmek istemedim. (Erkek, 30, Gar, Güvenpark, İstiklal)

Servise binmeye bile imtina ettim yani, servis bile kullanmamaya başladık, kendi aracımızla gidip gelmeye başladık. (Kadın, 44, Güvenpark ve Merasim Sk.) 
Benim için çok travmatik bişeydi. ... çok etkilendim ben bir süre Sincan garını kullandım. Erken indim o gara (Ankara Gar) gitmemek için. (...) Dolmuşla geçtim merkeze. (Kadın, 31, Güvenpark)

\subsubsection{Terörü Deneyimleyen Alanlardan Kaçınma}

Örneklemin kaçınma davranışı sergilediği bir durum ise daha önce terör eyleminin deneyimlenmiş olduğu mekân veya alanlara ilişkindir. Örneklemin toplamda \% 58,5'i daha önce bir terör eyleminin gerçekleştirilmiş olduğu alanlardan uzak durmaya çalıştığını ifade etmiştir. Bu sonuçları literatürle de desteklemek mümkündür. 9/11 saldırısından 18 ay sonra gerçekleştirilen bir çalışma, bir yıllık bir zaman diliminde milyonlarca Amerikalı'nın havayolu seyahatlerini azalttığını ortaya koymuştur (Gigerenzer, 2006: 348- 250). Terör korkusu sebebiyle ABD'de havayolunun kullanımındaki düşüşleri ortaya koyan başka çalışmalar da mevcuttur (Ito ve Lee, 2005). Aynı şekilde 2004 Madrid banliyö treninde gerçekleştirilen ve yaklaşık 200 kişinin hayatını kaybettiği bombalı saldırı,demiryolu seyahatlerinde bir düşüşü beraberinde getirmiştir (Gigerenzer, 2006: 350). Dolayısıyla toplu taşıma ağlarından örnekler olmakla birlikte bu örnekler terör saldırısının gerçekleştirildiği mecralarda bulunma yönündeki bir kaçınma davranışını somut olarak ortaya koymaktadır.

Ancak katılımcılardan elde edilen veriler, terörü deneyimlemiş olan mekanlardan kaçınma davranışına ilişkin çok yaygın rastlanılmamakla birlikte farkıı bir tutumun benimsendiğini de ortaya koymaktadır. Bu tutum, daha önce terörize edilmiş bir alanın ikinci kez aynı amaçla kullanılmayacağı düşüncesinden hareketle, bu alanları kullanmaktan korkmama ve kaçınmama şeklinde ortaya çıkmıştır. Görüşülenler tarafından bu durum, sıklıkla "aynı yere iki defa yıldırım düşmez” veciziyle ifade edilmiştir:

Yani eylemin daha önce gerçekleştiği yerde aslında belki daha güvende oluruz çünkü aynı yerde iki kere patlatmaz diye düşünüyorum ama. Çünkü matematiksel düşününce şansı düşer heralde. Ama kalabalık olan bi yerde bulunmamaya özen gösterdim. (Erkek, 24, Gar)

Ama burda o kadar yoğun olmadı (kaçınma). Çünkü bir yere bir daha saldırı olmaz diye düşündüm, keza da olmadı. (Erkek, 30, Gar) 
Ama mesela nişanlım bunu (kaçınma davranışını) yersiz buldu. Aynı yere ateş iki defa düşsmez mi, öyle bi laf var ya duymuşşsunuzdur belki. (....) Ya hani aynı yer iki kere mağdur olmaz tarzı bişey var, ... onu söyleyip duruyodu yani. (Kadın, 31, Güvenpark)

Kalabalık alanlardan, alışveriş merkezlerinden, toplu taşıma araçlarından ve eylemin daha önce deneyimlendiği alanlardan kaçınma davranışları birbirlerinden kesin sınırlarla ayrılacak davranışlar değildir ve kaçınma tavrı genellikle bir bütün olarak karşımıza çıkmaktadır. Genel olarak bu alanlardan birinden kaçınma davranışı diğerlerinden kaçınma davranışı ile aynı güdü tarafından tetiklenmektedir. Esasen kalabalıklardan kaçınma davranışının diğer mekanlardan kaçınma davranışının temel belirleyicisi olduğu söylenebilir. Nitekim terör ve korkunun eşleştirildiği mekânlar arasında, terör örgütlerince daha fazla ses getirmek amacıyla hedef olabileceği düşüncesiyle "kalabalık" önemli bir mekân olarak karşımıza çıkmıştır. Paris'te 2005'te meydana gelen terör saldırıları sonrası Paris'in merkezi meydanlarındaki bireylerle saldırıdan 1 hafta, bir ay ve iki ay olmak üzere üç süreçte yapılan anket çalışmaları, katılımcılarda önemli davranış değişiklikleri bulgulamışlardır. Buna göre, 1 hafta sonra elde edilen verilere göre, örneklemin \% 65,40 kaçınma davranışı belirtirken bu oran 1 ay sonra \% 81,50 düzeyine yükselmiş ve 2 ay sonra ise $\% 76,80$ düzeyine gerilemiştir. Kaçınma davranışının sergilendiği mekân ve durumlar ise; tren istasyonları, Eyfel Tur, alışveriş merkezleri, La Défense ve Châtelet semtleri, gösteriler ve Charlie Hebdo mağdurları şerefine halka açık toplantılar, vb şeklinde bulgulanmıştır (Pelletier ve Drozda-Senkowska, 2016).

\subsubsection{Kaçınma Davranışında İyileşme}

Terör korkusu ile kalabalık mekanlardan ve belirli bazı alanlardan kaçınma davranışında zaman içerisinde önemli ölçüde azalma meydana gelmiştir. Bunun temel nedenlerinden biri, zaman faktörünün kendisi, diğeri ise zamanla da bağlantılı olarak sürekli bir korkma ve kaçınma halinde yaşanamayacağının idraki ve bunun oluşturduğu kabullenme duygusudur.

Görüşülenlerden bazıları, başlangıç itibariyle kalabalık mekânlara, terörü deneyimlemiş alanlara girmekten kaçındığını ifade etse de zamanla bunun bir sınırının olmadığının idrak edildiği noktada insanların normal yaşantısına geri döndüğünü, “adımlarının yavaşladığını” ifade etmiştir: 
AVM'ye zaten gitmezdim, o dönemler AVM'ye hiç gitmez oldum. (...) Metrodan gerildim, metro kullanamaz hale geldim. (...) Ama böyle bişey de üstüne gelince ... yani şey yok, yapabileceğin hiç bişey yok. Sonra, bundan sonra zaten insanlar normal hayatına döndü. Dediler ki nereye kadar neyden kaçacaz. Otobüse eninde sonunda binmek zorundasın, metroya binmek zorundayım. Gideceksem, bi işim varsa AVM'ye gitmek zorundayım. Ya bunla yaşanmaz hele gelirsin düşüncesi hâkim olduğunda normal seyre döndük, sokaktaki adımlarımız yavaşladı. (Bu ne kadar bir süre aldı sizin için?) Bence bi 6- 7 ayımızı aldı. Yani hatırladığım kadarıyla, belki daha fazladır. Bazen fark edemiyosun çünkü. Bazen an an geliyor, bazen sürekli bazen an an, kesintili. (Kadın, 33, Gar ve Güvenpark)

Yukarıdaki ifadede yer alan "adım hızı", algılanan riskin ve korkunun şiddetini ve etki derecesini gösteren önemli bir ifadedir. Aynı kişi, terör saldırılarını takip eden kısa zaman dilimi içindeki kalabalık mekanları tüketim pratiğini anlatırken "uzun bir süre bi çoğumuz koşarak yürüdük bütün caddeleri" ifadesini kullanmıştır. Ancak gerek terör saldırılarının üzerinden geçen zaman süresi, ki bu süre görüşülenlerin büyük kısmı için ülkede gerçekleşen son terör saldırılarından sonraki 4 ila 6 ay sonrasını işaret etmektedir, gerekse bu durumdan hiçbir şekilde kaçış olamayacağı, bireysel tedbirlerin sınırlı olduğu düşüncesi bu adımların yavaşlamasına yol açmıştır. Adımların yavaşlaması, algılanan riskin ve korkunun şiddetinin azaldığını gösterirken aynı zamanda bir kabullenişi de ifade etmektedir. Suç korkusu bağlamında bakıldığında adım hızı özellikle kadınlar için karanlıkta ve tenha sokaklarda önemli bir gösteren durumundayken, terör söz konusu olduğunda adım hızını belirleyenin kalabalık, düzenli mekânlar olduğu anlaşılmaktadır.

Araştırmanın yapıldığı zaman diliminde, Ankara'da yaşanan son terör saldırısından 24 ay, Türkiye'de yaşanan son terör saldırısından 14 ay geçmesine rağmen algılanan riskin ve korkunun kaydadeğer bir düzeyde olduğu görülmektedir. Araştırmamız zamansal bir araştırma olmadığı için aradan geçen zaman dilimin korku üzerinde nasıl bir etki yarattığını doğrudan ortaya koymak mümkün olmamıştır. Ancak yine de hem anket hem de görüşmeler esnasında bireyler tarafindan zaman mevzuuna vurgu yapılmış ve zaman içerisinde endişelerinin nispeten azaldığı ifade edilmiştir. Nitekim geçmiş yıllarda yapılan 
birtakım araştırmalar $\quad$ (http://www.gallup.com/poll/4909/terrorism-UnitedStates.aspx\#1; https://www.nielsen.com/tr/tr/press-room/2017/q2-consumerconfidence.html) ve literatürde yer alan bazı çalışmalar (Nacos, Bloch- Elkon ve Shapiro, 2007: 114-115; Rubin vd., 2007) da teröre ilişkin risk algıs1 ve korkuda aradan geçen zamanın önemli bir değişken olduğunu ortaya koymuşlardır.

$\mathrm{Bu}$ durum görüşmelerden elde edilen verilerle de desteklenmektedir. Görüşme gerçekleştirilen bireylerin neredeyse tamamı, kendi terör korkularında zamana bağlı olarak gözle görülür bir azalma olduğunu ve bunun davranışlarına yansıdığını belitrmişlerdir:

Çok korktuğum zamanlar vardı. Dedim ya Kızılay’a gitmekten korkuyoduk, hatta gittiğimizde hadi ölecez abi falan gidelim diye. (...) Sonra, ama şimdi o kadar korktuğumu söyleyemem. Çünkü öncesinde mesela kalabalık görünce çok az bi kalabalık olsa da girmekten imtina ediyodum, girmesem mi, yolumu mu değiştirsem falan filan ama şimdi heralde aştım, ya da işte unuttuk. Üzerinden zaman geçti. (Erkek, 24, Güvenpark) 


\section{SONUÇ}

Chicago Okulu, hızlı kentleşme, nüfus artışı ve hetorejenleşmeyle ilişkili olarak suçu kırdan ziyade kentle birlikte değerlendirmiş ve suçu daha ziyade kentsel mekânda konumlandırmıştır. Daha önce de ifade edildiği gibi Shaw ve McKay tarafından geliştirilen düzensizlik teorisinde ise, suç, fiziki ve sosyal manada düzensizlik gösteren belirli kentsel mekânlarla ilişkisi içerisinde ele alınmıştır. Bu düzensiz mekânların toplumsal denetimi zayıflattığı ve bu durumun suç davranışını tetiklediği ifade edilmiştir (Hunter, 1978: 1; Dolu, 2015: 224- 227; K1zmaz, 2005: 152). Bu tartışma bağlamında terör göz önünde bulundurulduğunda, geleneksel anlamda terörün daha çok kırsal kesimde ve doğrudan militer güçler arasında gerçekleştiği görülmektedir. Türkiye özelinde bakılacak olursa terörist eylemlerin uzun yıllar Türkiye'nin belirli bir bölgesinde, özellikle sınıra yakın kırsal alanlarda ve askeri güçlere yönelik olarak gerçekleştirildiği bilinmektedir. Ancak son yıllarda Türkiye'de ve dünyada ortaya çıkan yeni terörizm dalgası bu eylemlerin gerçekleştirilme biçiminde de önemli dönüşümler ortaya çıkarmıştır. Terör artık devletlerin askeri güçlerine değil sivil halka yöneltilmeye başlanmış, eylemlerin kendisinden çok sonucunda ortaya çıkaracağı korkunun şiddeti ve kapsamı önemli hale gelmiştir. Ses getirebilme potansiyelinin terör için amaç haline gelmiş olması bu eylemlerin daha çok kayıpla sonuçlanmasıyla sağlanabileceği için bu eylemler çok büyük ölçüde büyük kentlerin kalabalık alanlarında gerçekleştirilmeye başlanmıştır. Bu durum terörün düzensizlik teorisi tarafından ortaya atılan perspektifle uyum sağlamadığını göstermektedir. Terör, diğer suçlardan farklı olarak (yankesicilik, kapkaç gibi belirli suçlar bu kapsam dışında bırakılabilir), fiziki ve sosyal olarak düzensiz olan mekânlarda değil tam da kentin en düzenli olan, en yoğun kullanılan, en heterojen mekânlarında gerçekleştirilmektedir. Düzensizlik teorisinde fiziki ve sosyal açıdan düzensiz mekânların denetimden yoksun olmasının suçun denetimini engellediği ifade edilmektedir. Ancak böylesi düzenli kentsel mekânlar da (terör eylemlerinin gerçekleştirilme biçimiyle ilişkili olarak) denetimi zorlaştırmaktadır. Suç korkusu literatürü göz önünde bulundurulduğunda "karanlık" suç eylemine maruz kalma korkusunun önemli bir tetikleyicisi olarak karşımıza çıkmaktayken, söz konusu terör olduğunda bu kavramın yerini “kalabalık”ın aldığını söyleyebiliriz. Karanlık, suç eylemini gerçekleştirenler açısından gizlenebilme, mağdur açısından ise savunmasız kalma ihtimalini arttırmaktadır. Terör eylemi açısından 
ise, kalabalık, hem eylemi gerçekleştirenin görünmez olabilmesine imkân tanımakta hem de bireylerin gündelik yaşam pratikleri içerisinde en beklenmedik şekilde mağdur olabilmelerine yol açmaktadır. Bu anlamda karanlık ve kalabalık farklı mağduriyetlere yol açan, fakat ikisi de korkuyu tetikleyen kavramlardir.

Bombalı terör eylemlerinin gerçekleştirilme biçimi düzensizlik teorisini olduğu gibi sosyal kontrol teorisini de korku ve mekan ilişkisi bağlamında işlevsiz kılmaktadır. Nitekim terör eylemine maruz kalınacak mekanlarda yakın çevrenin toplumsal açıdan bağlılık ve bütünlük göstermesi bir önem arzetmediği gibi olay öncesi müdahalede mekanizmalarını çalıştırmak suretiyle güven sağlaması da pek mümkün değildir. Ancak yakın çevrenin nüfus yapısı, sosyal dokusu, altkültürel çeşitlilik teorisi ile ilişkilendirildiğinde terör korkusu üzerinde nispeten etkili olmaktadır denilebilir. Nitekim görüşme verilerinde, bireyler kendilerinden kültürel, etnik, dini veyahut ideolojik olarak farklılık gösteren grupların yoğun olarak yaşadığı veyahut daha fazla heterojen olarak gördükleri belirli mekanlara ilişkin korku ve çekincelerini dile getirmişlerdir. Özellikle son yıllarda tüm dünyada din temelinde gerçekleştiren terör eylemleri dolayısıyla bu türden bir belleği canladıracak grupların bulunduğu bölgeler/ mekanlar doğrudan korku yaratmakta ve etiketlenmektedir. Benzemezliğin yarattığı bu korku, yalnızca bu azınlık gruplardan gelecek tehlikelere veya bu grupların bulunduğu mekanlara ilişkin değildir. Bu benzemezlik kişilerin kendilerini ve düşüncelerini hedef alacak terör mağduru olma korkusunu da beraberinde getirmektedir. Bu korkuyu, esasında suç korkusu değil mağduriyet teorileri olan yaşam tarzı ve rutin aktiviteler teorileriyle açıklamak mümkündür. Bu teorilere göre, yaşam tarzı farklılıkları, demografik farklılıklar (McNeeley, 2015: 33; Corkin vd., 2015: 406- 42), motive olmuş suçlular, uygun hedefler ve hedefi suçludan koruyacak koruyucuların yokluğu gibi unsurlar mağduriyet yaratan faktörlerdir (Cohen ve Felson, 1979: 589; Felson, 1997: 209).Görüşmeler sonucu elde edilen veriler, bazı bireylerin yaşam tarzlarından, ideolojik angajmanlarından kaynaklı farklılıkları ve bu farklılıkların ortaya çıkardığı sosyal ilişki biçimlerinin kendilerini hedef haline getirdiğini ifade etmişlerdir. Düşünce ve yaşam tarzı benzerliği sonucu ortaya çıkan organizasyonel ilişkiler ve bu ilişkilerin belirli zaman ve mekanlardaki görünürlüğü ve erişilebilirliği bu gruplar içerisinde bulunan 
bireylerin terör korkularını ve korkularının mekanla ilişkisini bu ideolojik etkinliklerle açıklamaları sonucunu doğurmuştur. İdeolojik eylemler ve bu eylemlerin gerçekleştirildiği mekanlar temelinde ortaya çıkan bu korkuyu arttıran bir diğer faktör ise, kendilerini bilinçli veya bilinçsiz olarak koruyacak unsurların olmadığına ilişkin inançtır. Bu durum terör eylemlerini doğrudan deneyimlemiş olan katılımcılarımızın önemli bir kısmının mağduriyet korkusunu açıklayacak önemli bir unsur olarak yaşam tazı teorisini önemli kılmaktadır.

Terör korkusu mekan ilişkisinde ortaya çıkan bir diğer husus belirli bir mekandan bağımsız olarak her yerde bu korkunun hissedildiğine ilişkin görüşlerdir. Araştırma verileri, örneklemin bir kısmının riskin küreselleşmesi teziyle uyumlu olarak her an ve her yerde teröre maruz kalabileceğini ve dolayısıyla korkularının belirli bir mekanla sınırlı olmadığını ifade ettiklerini göstermektedir.. Risk toplumunda yaşıyor olmanın sonucu olarak bireyler, hayatta kalmalarının bir tesadüf olduğunu ve her an terör mağduru olmanın sınırında yaşadıklarını ifade etmişlerdir. Dünya risk toplumu teziyle ilişkilendirilebilecek bir diğer bulgu ise, katılımcıların teröre ilişkin korkularını terör deneyimi yaşamadıkları veyahut bu deneyimin hiç yaşanmadığı mekanlara aktarmalarıdır. Mekanların çeşitli özellikleri arasında kurulan bağlar, bu mekanları olası terör mekanları arasına sokmakta ve bu durumu tüm ülke hatta dünyaya genelleyebilmektedir.

Ancak bulgular genel itibariyle göstermektedir ki, bireyler, belirli mekânları diğerlerinden daha çok terörle özdeşleştirerek bu mekânlarda daha fazla korku duymakta ve daha fazla kaçınma davranışı sergilemektedirler. Alışveriş merkezleri, toplu taşıma ağları ve diğer kalabalık mekanlar, ideolojik eylemlerle ilişkilendirilen mekanlar, güvenlik güçlerinin yoğun olarak yer aldığı mekanlar, daha önce bir terör saldırısını deneyimlemiş olan mekanlar korkunun "her yer"den daha fazla hissedildiği mekanlardir.

Ancak bu bulgular, bize bir yerde gerçekleşen terör olaylarının çok uzak coğrafyalarda aynı korku ve tepkiye yol açacağını göstermediği gibi, korkunun yalnızca onu ortaya çıkaran coğrafi mekânla sınırlı kaldığını da göstermez. Korkunun belirli bir mekanla veya alanla özdeşleştirilmesinde temel faktör 
geçmiş terör deneyimleridir. Bu deneyimler, terörün nerede konumlandığını, ortaya çıktığı alanın fiziksel ve demografik yapısını, aktörlerinin etnik, dini, ideolojik arkaplanlarını, hedef gruplarını kodlayarak bireysel ve toplumsal bir hafıza yaratmaktadır. Nitekim, geçmiş deneyimleri büyükşehirlerin terör manasında "beklenmeyen" mekanı iken sonraki deneyimler bu mekanları terörün en çok beklendiği mekanlar olarak hafızalara kodlamıştır. Dolayısıyla belirli mekanlar korkunun daha fazla görünür olduğu mekanlar olarak karşımıza çıkmaktadır. 


\section{SUMMARY}

Crime and fear of crime is a significant problem that is experienced more frequently in cities, especially as a result of industrialization and rapid urbanization. Terrorism is another problem that has come to the forefront as an urban problem in almost every part of the world in recent years. In recent years, terrorist attacks have been carried out, especially in certain urban spaces, as they allow the creation of a society of fear. This situation leads to the emergence of fear of terrorism as another problem as significant as terrorism. In this study, the relationship between the fear of terrorism and space is discussed in terms of theories of fear of crime, and it has been tried to determine whether there are places where fear of terrorism is felt more.

The theoretical framework of the research consists of theories of disorder, social concern/control and subcultural diversity which are the theories of social disorganization that address the fear of crime in the context of the physical and social characteristics of space. The theory of disorder treats the presence of signs of physical and social danger related to disorder in the environment as elements of fear of crime. Social concern/ control theory considers the disintegration in the social structure of the environment, and subcultural diversity theory considers ethnic and cultural heterogeneity as elements of crime fear. Theory of world risk society is another theoretical context within the scope of the research. According to this theory, in the age of globalization, risks create an impact beyond space and time and enclose everyone.

For the last few years, several terror attacks were carried out targeting civilians in some urban areas in Turkey. Suruç (2015), Ankara Train Station (2015), Kızılay (2015), Istiklal Street (2016), Sultan Ahmet (2016), Atatürk Airport (2016), and Reina (2017) are some of these areas. To determine whether these attacks caused fear of terror on a spatial basis, 400 surveys were conducted in Ulus and Kizilay, where terrorist attacks had previously taken place. Besides, 20 interviews were conducted with individuals who had experienced at least one of these attacks directly. 
The results of the research reveal that the fear of terror is more exposed in crowded places, shopping malls, public transport hubs, in places where they had experience of terrorism, in places associated with certain ideology and religion, and in places where security forces are located. Unlike the theories of disorder and social concern/control, the research results show that the fear of terror does not occur physically and socially in disorder places and darkness, but rather in the most organized places and crowds of the city. The theory of subcultural diversity, which is one of the theories explaining the fear of crime, is relatively confirmed by the conclusion that fear of terror is felt more in the areas where radical religious groups live. In spite of some statements that terrorism can take place anywhere and any time, the fact that certain places are more related to fear does not make the world risk society theory completely useful. In short, the research results show that the fear of terror is more felt in certain urban spaces due to the social memory created by past experiences and leads to more avoidance behavior. 


\section{KAYNAKÇA}

Ahmed, S. (2015). The Emotionalization of the "War on Terror": Counterterrorism, Fear, Risk, Insecurity and Helplessness. Criminology \& Criminal Justice, 15(5), 545-560.

Aly, A., Green, L. (2010). Fear, Anxiety and the State of Terror. Studies in Conflict \& Terroris, 33: $268-281$.

Beck, U. (2014). Risk Toplumu Başka Bir Modernliğe Doğru. (Çev. K. Özdoğan ve B. Doğan). İstanbul: İthaki Yayınları.

Beck, U. (2006). Living in the World Risk Society: A Hobhouse Memorial Public Lecture Given on Wednesday 15 February 2006 at the London School of Economics. Economy and Society, 35(3), 329-345.

Beck, U. (2005). Siyasallı̆ğn İcadı. (Çev. N. Ünler). İstanbul: İletişim Yayınları.

Beck, U. (2002a). The Terrorist Threat: World Risk Society Revisited. Theory, Culture \& Society, 19(4), $39-55$.

Beck, U. (2002b). The Silence of Words and Political Dynamics in the World Risk Society. Logos, 1(4), $1-18$.

Box, S., Hale, C., Andrews, G. (1988). Explaining Fear of Crime. The British Journal of Criminology, 28 (3), 340-356.

Bunch, J., Clay-Warner, J., Lei, M. K. (2015). Demographic Characteristics and Victimization Risk: Testing the Mediating Effects of Routine Activities. Crime \& Delinquency, 61(9), 1181-1205.

Cohen, L. E. and Felson, M. (1979). Social Change and Crime Rate Trends: A Routine Activity Approach. American Sociological Review, 588-608.

Connerton, P. (2009). How Modernity Forgets. Cambridge: Cambridge University Press.

Corkin, D., Wiesner, M., Reyna, R. S., Shukla, K. (2015). The Role of Deviant Lifestyles on Violent Victimization in Multiple Contexts. Deviant Behavior, 36(5), 405-428.

Covington, J. and Taylor, R. B. (1991). Fear of Crime in Urban Residential Neighborhoods. The Sociological Quarterly, 32(2), 231-249.

Demirçivi, E. R. (2015). Metropollerde Terörizm Algısı: Ankara'da Bir Uygulama. Yayımlanmamış Yüksek Lisans Tezi. Ankara: Kara Harp Okulu Savunma Bilimleri Enstitüsü. 
Dolu, O. (2015). Suç Teorileri. Ankara: Global Politika ve Strateji Yayınları.

Dönmezer, S. (1994). Kriminoloji. İstanbul: Beta Basım Yayım Dağıtım.

Durodie, B. (2007). Fear and Terror in a Post-Political Age. Government and Opposition, 42(3), 427450.

Felson, R. B. (1997). Routine Activities and Involvement in Violence as Actor, Witness, or Target. Violence and Victims, 12(3), 209-221.

Garrison, A. H. (2004). Defining Terrorism: Philosophy of the Bomb, Propaganda by Deed and Change through Fear and Violence. Criminal Justice Studies, 17(3), 259-279.

Giddens, A. (2004). Modernliğin Sonuçları. (Çev. E. Kuşdil). İstanbul: Ayrıntı Yayınları.

Giddens, A. (2000). Elimizden Kaçıp Giden Dünya. (Çev. O. Akınhay). İstanbul: Alfa Yayınları.

Gigerenzer, G. (2006). Out of the Frying Pan into the Fire: Behavioral Reactions to Terrorist Attacks. Risk Analysis: An International Journal, 26(2), 347-351.

Hale, C. (1996). Fear of Crime: A Review of the Literature. International Review Of Victimology, 4:79150.

Hartnagel, T. F. (1979). The Perception and Fear of Crime: Implications for Neighborhood Cohesion, Socialactivity, and Community Affect. Social Forces, 58(1), 176-193.

Hindelang, M. J., Garofalo, J., Gottfredson, M. R. (1978). Victims of Personal Crime: An Empirical Foundation for a Theory of Personal Victimization. Cambridge: Ballinger Publications.

Howie, L. (2005). There is Nothing to Fear but Fear Itself (and Terrorists): Public Perception, Terrorism and the Workplace. Paper Presented to the Social Change in the 21st Century Conference. Centre for Social Change Research Queensland University of Technology.

Hunter, A. (1978). Symbols of Incivility: Social Disorder and Fear of Crime in Urban Neighborhoods. https://www.ncjrs.gov/pdffiles1/nij/82421.pdf. (Erişim Tarihi: 02.03.2017).

Irmak, F. ve Kahya, Y. (2014). Amerika Birleşik Devletleri'nde Terörizm ve Terörizm Korkusu: 11 Eylül Terör Saldırılarının Öncesi ve Sonrasına Ilişkin Bir Analiz. Uluslararası Sosyal Araştırmalar Dergisi, 7(33), 315- 324.

Ito, H., Lee, D. (2005). Assessing the Impact of the September 11 Terrorist Attacks on US Airline Demand. Journal of Economics and Business, 57(1), 75-95. 
Khruakham, S., Lee, J. (2014). Terrorism and Other Determinants of Fear of Crime in the Philippines. International Journal of Police Science \& Management, 16(1), 1-15.

Kızmaz, Z. (2005). Sosyolojik Suç Kuramlarının Suç Olgusunu Açıklama Potansiyelleri Üzerine Bir Değerlendirme. CÜ Sosyal Bilimler Dergisi, 29(2), 149-174.

Laqueur, W. (2000). The New Terrorism: Fanaticism and the Arms of Mass Destruction. USA: Oxford University Press.

Lewis, D. A., Salem, G., Szoc, R. (1980). Crime and Urban Community: Towards a Theory of Neighborhood Security. Reactions to Crime Project, Center for Urban Affairs, Northwestern University.

Liska, A. E., Lawrence, J. J., Sanchirico A. (1982). Fear of Crime as a Social Fact. Social Forces, 60(3), 760-770.

McGarrell, E. F., Giacomazzi, A. L., Thurman, Q. C. (1997). Neighborhood Disorder, Integration, and the Fear of Crime. Justice Quarterly, 14(3), 479-500.

McNeeley, S. (2015). Lifestyle-Routine Activities and Crime Events. Journal of Contemporary Criminal Justice, 31(1), 30-52.

Mühürcüoğlu, E. (2010). Bombalı Intihar Saldırısı Sonucu Oluşan Suç Korkusu Üzerine Bir Vaka İncelemesi: Ulus-Anafartalar Çarşısı Örneği. Yayımlanmamış Yüksek Lisans Tezi. Ankara. Hacettepe Üniversitesi.

Mythen, G., Walklate, S. (2008). Terrorism, Risk and International Security: The Perils of Asking 'What if?'. Security Dialogue, 39(2-3), 221-242.

Mythen, G., Walklate, S. (2006). Criminology and Terrorism: Which Thesis? Risk Society or Governmentality?. British Journal of Criminology, 46(3), 379-398.

Nacos, B. L., Bloch-Elkon, Y., Shapiro, R. Y. (2007). Post-9/11 Terrorism Threats, News Coverage, and Public Perceptions in the United States. International Journal of Conflict and Violence (IJCV), 1(2), 105-126.

Nellis, A. M., Savage, J. (2012). Does Watching the News Affect Fear of Terrorism? The Importance of Media Exposure on Terrorism Fear. Crime \& Delinquency, 58(5), 748-768.

Pain, R., Smith, S. J. (2008). Fear: Critical Geopolitics and Everyday Life. In Fear: Critical Geopolitics and Everyday Life, 1-24. Aldershot: Ashgate. 
Pain, R. (2009). Globalized Fear? Towards an Emotional Geopolitics. Progress in Human Geography, 33(4), 466-486.

Pain, R.H. (2010). The New Geopolitics of Fear. Geography Compass., 4 (3), 226-240.

Pelletier, P., Drozda-Senkowska, E. (2016). The Charlie Hebdo Terror Attack in Paris: Follow-up of French Citizens' Terrorist Threat Perception and Its Aftermath. International Review of Social Psychology, 29(1).

Policastro, C. (2013). Victimization of the Elderly: An Application of Lifestyles/Routine Activities Theory. Georgia State University. http://scholarworks.gsu.edu/cj_diss/1 (Erișim Tarihi: $\underline{01.05 .2017) .}$

Rubin, G. J., Brewin, C. R., Greenberg, N., Hughes, J. H., Simpson, J., and Wessely, S. (2007). Enduring Consequences of Terrorism: 7-Month Follow-up Survey of Reactions to the Bombings in London on 7 July 2005. The British Journal of Psychiatry, 190(4), 350-356.

Sanadjian, M. (2006). Fear, Terror and the New Global Economy of Salvation - Global Excess and 'Suicide' Bombing in London. Social Identities, 12(6), 701-725.

Semmerling, T. J. (2008). Those "Evil" Muslims! Orientalist Fears in the Narratives of the War on Terror. Journal of Muslim Minority Affairs, 28(2), 207-223.

Skogan, W. (1986). Fear of Crime and Neighborhood Change. Crime and Justice, 8, 203-229.

Taylor, R. B., Hale, M. (1986). Testing Alternative Models of Fear of Crime. Journal of Criminal Law and Criminology, 77(1), 151- 189.

Warr, M. (1990). Dengerous Situations: Social Context and Fear of Victimization, Social Forces, 68, 891-907.

Wilson, J. Q., Kelling, G. L. (1982). Broken Windows. (p.1-10). https://www.manhattaninstitute.org/pdf/ atlantic monthly-broken windows.pdf (Erișim Tarihi: 28.04.2017).

Wirth, L. (2002). Bir Yaşam Biçimi Olarak Kentlileşme. (Çev: B. Duru ve A. Alkan). B. Duru ve A. Alkan (Ed.), 20. Yüzyıl Kenti içinde (s.77- 106). Ankara: İmge Kitabevi. 